\title{
Education for Sustainable Development in Indonesia: Developing Online Sustainable Development Learning Model Based on Indonesian Typical Case Studies
}

\begin{abstract}
Ali Murtopo Simbolon*
Sustainable Development Expert, Ministry of Industry, Indonesia

*Corresponding author. Email: ali_simbolon@yahoo.co.id

ABSTRACT

People need Education for Sustainable Development to support their productivity and creativity in facing global challenges. This helps making a more versatile and sustainable society. It also empowers each person to develop their intelligence, competence, character, and attitude needed in forming an awareness and real efforts in achieving sustainable development goals. Indonesia in particular needs a framework of education for sustainable development; we need a way of learning sustainable development easily accessible by everyone. This study aims to develop an online sustainable development-learning model based on Indonesian typical case studies. This study uses the Dick, Carey, and Carey learning model including preliminary research, identifying learning objectives, carrying out analysis and learning context, making performance or competency objectives, creating appraisal instruments, developing methodologies, creating and choosing learning materials, planning and implementing online evaluation (formative and summative). Typical Indonesian case facilitates a contextual understanding of the problems of sustainable development in Indonesia. The target of this model is college student level. A formative evaluation includes reviews and evaluations from learning experts, sustainable development experts, human and computer visual communication experts, and sustainable development practitioners. The results of the evaluation helps to improve the learning model. The final model will be implemented as an online sustainable development learning model based on Indonesian typical case studies.
\end{abstract}

Keywords: Online learning, Sustainable development, Education for sustainable development.

\section{INTRODUCTION}

Indonesia is committed to achieving the goals of sustainable development for 2015-2030. The Sustainable Development Goals consists of 17 objectives outlined in the Presidential Decree No.59 of 2017 concerning the Implementation of the Sustainable Development Goals [1]. Apart from technological solutions, political regulation, and financial development, education is crucial for sustainable development [2]. Education is the key to help develop a person's productivity and creativity in facing global challenges thus making a versatile and sustainable society [3][4]. In Indonesia, education for sustainable development should be accessible to everyone. For this reason, this study analyzes online sustainable development learning model based on Indonesian typical case studies of Management Model Online
Learning Quality Assurance in Entrepreneurship Subject at Bina Insani University after the Covid-19 Pandemic.

\subsection{Model Development}

\subsubsection{Learning Development}

Developing the learning process entails a continuous and reliable process where training programs are updated to ensure good education. General systems theory and systems analysis is an initial approach in solving problems that occur in the learning process. Developing the implications of learning theories on learning development, where the interaction and continuity of learning theories support and complement each other [5]. Learning objectives can be achieved by combining and integrating learning theories according 
to the learning context so that learning can be effective and efficient.

\subsubsection{Model for Learning and Development}

One of the most popular and influential learning development models was created by Dick, Carey, and Carey as shown below [6]:

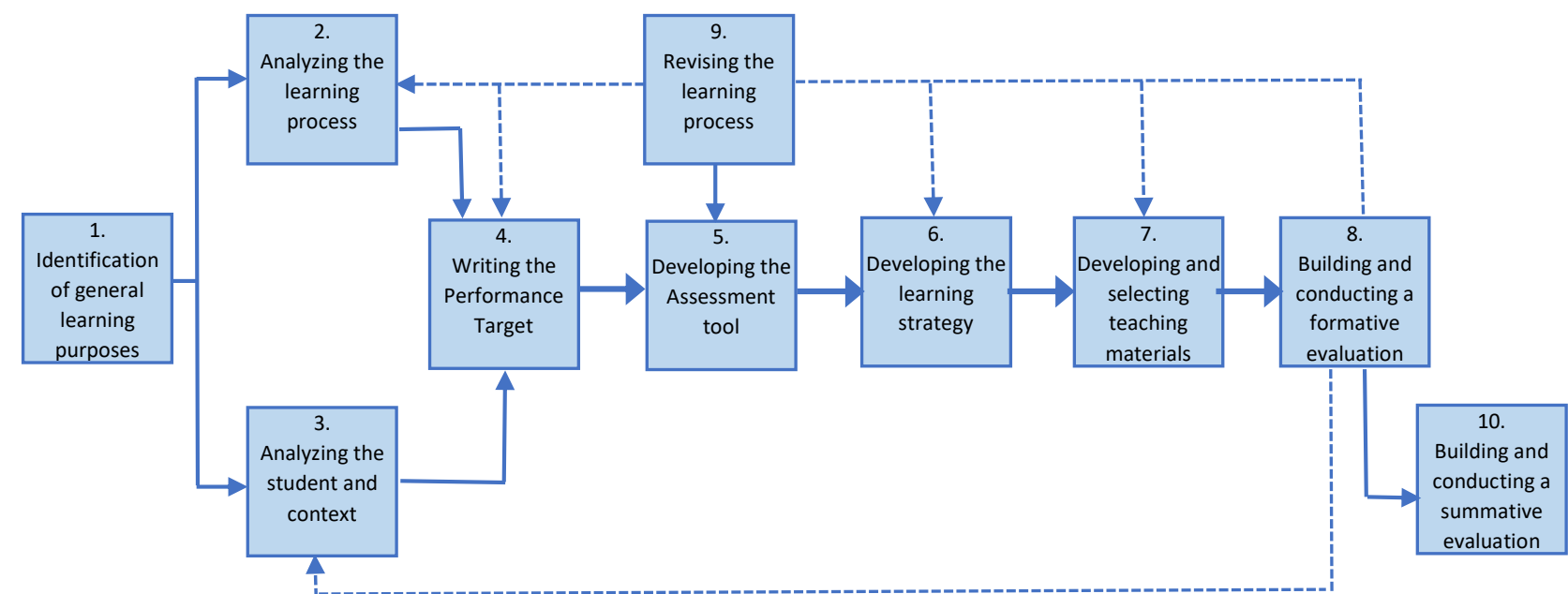

Figure 1. Image of Dick, Carey, and Carey Learning Design Model [6].

This research uses the Dick, Carey, and Carey learning development model. This approach was chosen because this approach can be applied both to formal education in schools or colleges, and non-formal education and this model is suitable for developing virtual learning in sustainable learning through direct theory and practice [6]. In addition, the selection of this model is more systematic and focuses on learning so that in addition to meaning, ease of implementation is also obtained from this model.

The Dick, Carey, and Carey model is built on the principles of learning. With systematic stages and systemic thinking patterns, this model involves stakeholders in learning, namely students, experts, lecturers, and the user community. Identifying learning needs and writing general learning objectives, analyzing learning, identifying behaviors and initial characteristics of learners are called the identification stage. Complete and accurate information is built in the development stage by composing a specified learning goal, composing benchmark reference tests, creating learning systems and creating learning stuffs. The material developed is then carried out a formative evaluation for feedback in making improvements. Formative evaluation is carried out every time towards continuous improvement. Improvements are made through reviewing the previous stages so that a back and forth cycle can be carried out. This is done so that the development of learning in the Dick, Carey, and Carey Model is a set of interconnected stages and corrections can be made at each stage.

It is through this cycle that continuous improvements to learning are made. A holistic and systemic approach, integrated with this model results in more effective and efficient products. Moreover, the simplicity and practicality of the concepts, principles, and procedures are explained in each step of the Dick, Carey, and Carey Model. Besides that, this model is also felt to be suitable for the development of online learning as it will also be developed in this study.

\subsection{Online Learning}

Snyder argues that certain attributes of computers are expected to bring genuine models and reenactments to students; learning is not influenced by media. Computers do not make students learn and study, however the plan of genuine models and reenactments, and also the learner's interactions. Computers are just tools that provide processing capabilities and instructions for learners [7]. However, learning materials must be well designed to engage learners and promote learning [8]. Online learning allows flexibility of access, from anywhere and at any time. This interaction was described as essential for effective learning and occurs when the learning climate is learner-centered, knowledge-centered, assessmentcentered, and community-centered.

Interactivity is viewed as a central principle of online learning theory. Utilizing web-based learning media gives a remarkable occasion to educators to connect with students in a variety of activities and offers another dimension to high-level, active interaction [9]. Another viewpoint of the internet learning theory is the network or social segment of web-based learning. Interaction in online forums promotes a feeling of community or social connectivity among students and teachers. The degree of connectedness between students brings the formation of productive relationships between class individuals and in a collaborative exploration of the topic [10]. The past research has 
demonstrated that learning communities show increased students learning and satisfaction [11].

\subsection{Online Case-Based Learning}

Dialogue and interaction are key components of a constructive environment in which learners construct and negotiate their arguments and ultimately produce the final product in an online environment [12]. Actionoriented activities and discussions feature the extended learners' role. Furthermore, the responsibility of the teacher serves as a catalyst, namely through study guides or facilitators.

Technology support is an important component in carrying out case-based learning in a web-based environment, where technology is the primary mechanism for instruction, correspondence, and cooperation. In the reality, the role of technology has advanced in both face-to-face and web-based learning conditions as it assumes the role of a cognitive tool that supports meaning creation and knowledge sharing with fellow students and specialists.

Furthermore, ongoing development in technology permit teachers to coordinate various technology tools such as asynchronous discussion forums, chat rooms, synchronous meeting tools, or multi-way conferencing (e.g. Microsoft NetMeeting, Macromedia Breeze, Zoom, MS Team, and Google Classroom) for discussion and case reflection. In addition, innovation can uphold educators in the event of advancement and presentation. Because multimedia is considered in enhancing the contextual comprehension of a case, its utilization is recommended as it can be an effective delivery tool for cases [13].

The main concerns of online case learning are that a technology platform is needed that can be used together and new materials must be prepared. Furthermore, for students that it is necessary to understand the needs of students, learning instructions are needed, challenges in measuring participation, and discipline. For the instructor that a different role is needed apart from being a facilitator, so that training and support are needed, and more time is needed to monitor learning. In this study, cases in urban and poverty, forestry and plantation, mining, manufacturing, and energy sectors were selected. Because this sector actually has a big impact on the national economy, absorbs a large number of workers, has a multiplier effect on other sectors to revive the economy.

On the other hand, it will have an impact on the environment, which will seriously damage the environment if not well controlled. Likewise, the impact on social aspects varies greatly between positive and negative, depending on the context and the people. Apart from developing case studies of manufacturing in Indonesia, the development of sustainable learning is not limited so that the learning materials that are built must accommodate the needs of learners to develop in other case studies, for example for mining, agriculture, forestry, poverty alleviation, and others.

\section{RESEARCH METHODOLOGY}

Instructional materials developed as a physical model. Development of online learning models followed the steps of the Dick, Carey, and Carey models and in that process, formative evaluation and model revision were carried out. The steps taken in the validation, evaluation, and revision of the Model were Designing and Implementing Formative Evaluations. The stages carried out were [6]:

a. Determining the population and research sample, the research population was all students. Meanwhile, the research samples at the time of the formative trial or evaluation were 3 students who had attended lectures, 2 experts on sustainable development, 2 experts in the development of learning materials, and 2 experts in information technology;

b. Developing online instruments and learning materials for sustainable development and were applied to the research subject as stated above.

\section{RESULTS}

The development of teaching materials aims to identify learning objectives. The identification of learning objectives is to assess information gaps from the start of the study. Thus, the formulation of learning objectives, namely: "Students will be able to understand Indonesia's Sustainable Development so that they have the awareness to make it happen in Indonesia."

Learning Analysis includes:

a. Student context analysis

- Student initial behavior analysis and student initial characteristics.

- Writing performance analysis or competency goals.

- Developing assessment instruments.

b. Measuring the level of mastery of each student

Learning experiences are the preparation of studies or papers related to competencies at each stage of learning. Papers for each competency will be integrated into the achievement of learning objectives in the form of integration into one study related to the implementation of monitoring and evaluation aimed at designing and developing monitoring and evaluation in the field of sustainable development under the field of interest. So, the reference test can assess the paper or study as a whole. 
c. Tracking student interactions with cases

Studies involving computers in case-based learning can track and report components of student access to cases such as comments, questions and resources they posted during case learning, and the duration of time spent studying with incidents;

d. Feedback by experts on student learning outcomes includes:

- Appropriateness of the contents of the case;

- The level of detail and difficulty and perceived usefulness of the case;

- Self-reporting by students regarding the quality of incidents against the use of other incidents;

- The amount of learning by thinking through individual or collective cases in groups;

- Adequacy of the number of cases;

- Case realism;

- Content level;

- Level of challenge and fun;

- Time to solve problems;

- Components of the case that contribute to learning.

After compiling the assessment instrument, the next step is to develop an instructional strategy and develop instructional materials. The result of this learning development has been included in a teaching material product that has been uploaded on the internet so that it can be used. Offline material is available in printed textbooks that can be downloaded from the website.

The model above is then used for a formative evaluation. The instrument for the material, design, and media production is used to conduct a formative evaluation. The instruments developed for the five aspects above are as follows:

a. The material for sustainable development is about the completeness of sustainable development material, the suitability of the stages of learning material, the suitability of cases developed with learning topics, and the urgency of cases following field problems in Indonesia

b. The design and development of learning materials are about learning objectives, learning needs, consistency of learning materials with objectives, interface design in e-learning software applications (delivery strategies) that accommodate learning theories, and the quality of learning exercises

c. Media production (information technology) is about interface design in e-learning software applications (delivery strategies) and the quality of e-learning software applications (ease of use and completeness of content)

d. Instrument validation. Three instrument experts validate the questions developed above first through a review. So that it can measure/evaluate learning materials appropriately

e. Collecting data for formative evaluation is the stages of a formative trial as follows:

- The first stage is evaluation from experts, namely two monitoring and evaluation experts in the field of sustainable development, two learning material development experts, two information technology experts to get input and corrections from existing materials. Data collection from experts was carried out through questionnaires and interviews. The questions used are a combination of multiple choices and open-ended to get useful and unlimited information related to the learning materials that have been developed.

- The second stage is to make revisions according to expert opinion.

- The third stage is the evaluation of 3 students who have participated in sustainable development learning to get input and corrections from revised materials based on expert opinions. The selected students are students who have characteristics in the target population. The three students selected come from students who have moderate, above moderate, and below moderate abilities so that they can be seen as a representative sample.

- The fourth stage is the collection of data from students who are taking lectures by directly using learning materials that have been developed online. Responses will be stored in the form of input and comments in learning materials as well as a final assignment in the form of developing a monitoring and evaluation program in a case of sustainable development of interest.

\section{DISCUSSION}

In this case-based learning innovation, technological support has increased the quality of case-based learning. Its capacity to generate the most recent cases on the web, permitting students to examine and talk about the learning materials wherever students are. In this online learning environment, feedback is obtained from teachers and experts thereby providing timely insight into how to resolve and solve the problem or situation embedded in a case. In addition, the multimedia learning component - text, video, animation, narrative, etc., can encourage understudies get more comprehension of the ideas and principles surrounding the case [14].

A case is described with a rich set of circumstances, issues, information, and abilities to be utilized, which serves to support and also help transfer learning to a 
variety of work settings. Moreover, educating and studying through strong case studies would give a more rich and credible experience to students. This kind of learning provides students with a challenge by providing authentic experiences of genuine circumstances.

There are three aspects of case-based learning in an online setting that must be considered and applied properly, namely:

a. Instructional plan for case development and delivery,

b. Facilitation of learner involvement in internet or web-based learning, and

c. Technology that support for effective case-based exercises.

From an instructional design point of view, well developed and designed learning materials and also activities are very important in manifesting an effective process of the learning. What sorts of cases are considered more effective? How do teachers organize case-related activities? What level of control do understudy has in the diverse case designs?

The cases highlight various concepts and introduce a wide variety of procedures. With giving some cases, learners can be experts in interpreting, analyzing, asking questions about ideas, and solving problems. The issues place on cases, circumstances, and situations used to analyze and explain the intricacy of practice. As a psychological activity, students start to move from beginner status and gain an expert point of view in the field. Facilities are another important key in realizing successful case-based learning, which guides to learner involvement requiring the teacher to use interrogation and discussion techniques through feedback.

In an online environment, dialogue and interaction are key things of a constructive climate where learner negotiates through their contentions and eventually produce their final or end result. Action-oriented exercises and conversations feature extended jobs and duties. An important element for facilitation is applying pedagogical techniques that guarantee a student's contribution in knowledge building, linking the case to knowledge, expanding, and transforming knowledge for actual situations. Techniques such as questioning, feedback, or guidance can help learners activate their meta-cognition and explore the implications of what they get through peer and teacher support.

A face-to-face case study strategy does not generally perform well when executed by using technological tools. Innovation uphold is a basic segment of completing case-based learning in an online climate, while innovation is the fundamental medium in which instruction, communication, and collaboration take place. The role of technology has advanced in both face-to-face and web-based learning conditions [13] as it assumes the role of a cognitive tool that supports meaning creation and knowledge sharing with fellow students and specialists.

Successful online learning should create an environment where the teacher engages students in a series of cases, like classroom-led case discussions. A system should be developed so that students generate conceptual relationships and debate key points, and make it possible to provide comparison cases, expert comments, and reasoning chain screens. The program developed in online learning has enabled teachers to integrate various technological tools such as asynchronous discussion forums, chat rooms, and multiway conferencing for discussion and case reflection. A case-based learning approach can be viable in an online climate. This reflects students' positive perceptions of case-based learning practices in the web-based environment.

This research shows students learn effectively during case-based online learning activities [15]. Teachers are encouraged to develop tools that allow students to produce theoretical connections and discuss significant issues, thus enabling them to make comparison between cases and receive expert comments [16].

\section{SCOPE AND LIMITATIONS}

a. This learning material is for Doctoral program students. It is not suitable for use by nonpostgraduate students. However, the learning system model and material development method acquired can be a reference in adjusting this online learning system into other courses;

b. The software has not yet gone through the software testing required to test the quality of the software.

\section{CONCLUSION}

a. Research and development use the Dick, Carey, and Carey learning development model by combining the steps in the instructional development model (MPI). Researchers develop and modify at the stage of developing learning strategies and develop and select learning materials. Case studies become the focus of learning as outlined in the exercises. Online and offline delivery methods;

b. The typical Indonesian case becomes the main reference and activity in each exercise to achieve specific competencies at each learning stage;

c. The physical model of online sustainable development learning materials based on typical Indonesian case studies is available online. Physical models integrate conceptual models, namely the implications of learning theory in web-based learning design (online), and make conclusions in learning activities;

d. The physical design of learning uses a system 
accessible to all students. There are also downloadable textbooks to study offline. During case-based learning in a web-based environment, comment and feedback from teachers and experts can help give valuable insights to solving cases. A case illustrated with a context of the situation, problems, knowledge, and skills support and also help transfer learning to a variety of work settings.

\section{SUGGESTION}

a. It needs a summative evaluation of learning materials. Qualitative and quantitative approaches will be convenient to see more deeply the effectiveness of teaching materials. The qualitative approach refers to the final stages mentioned in the Dick, Carey, and Carey model. The quantitative approach is to do experiments;

b. This model becomes an input for other learning (courses or other subjects) because there are universal components.

\section{REFERENCES}

[1] President of Indonesia. PERPRES No. 59 Tahun 2017 tentang Pelaksanaan Pencapaian Tujuan Pembangunan Berkelanjutan [JDIH BPK RI] [Internet]. Jakarta: Government of Indonesia; 2007 [cited 2021 Jan 14]. Available from: https://peraturan.bpk.go.id/Home/Details/72974/pe rpres-no-59-tahun-2017

[2] Chattaraj SK. Education for Sustainable Development. Int J Trend Sci Res Dev [Internet]. 2017 Dec 31 [cited 2021 Jan 14]; Volume-2(Issue1):131-4. Available from: https://www.ijtsrd.com/humanities-and-thearts/education/5889/education-for-sustainabledevelopment/santosh-kumar-chattaraj

[3] Bernardes ÂDC. Education for Sustainable Development Review. EccoS - Rev Científica [Internet]. 2020 Sep 30 [cited 2021 Jan 14];54(54). Available from: https://doi.org/10.5585/eccos.n54.16138.

[4] Draghici A, Mircea G, Ivascu L, Robescu DF. A Training Needs Assessment for Teaching and Educating Sustainability. Balk Reg Conf Eng Bus Educ [Internet]. 2020 May 26 [cited 2021 Jan 14];1(1):398-405. Available from: https://www.researchgate.net/publication/3416451 72_A_Training_Needs_Assessment_for_Teaching _and_Educating_Sustainability

[5] Shambaugh N, Magliaro. SG. Instructional design: a systematic approach for reflective practice [Internet]. Boston: Pearson/A and B; 2006 [cited 2021 Jan 14]. 1-317 p. Available from: https://trove.nla.gov.au/work/11558383

[6] Dick W, Carey L, Carey JO. The Systematic
Design of Instruction [Internet]. 7th ed. Pearson; 2009 [cited 2021 Jan 14]. Available from: https://www.pearson.com/us/highereducation/product/Dick-Systematic-Design-ofInstruction-The-7th-Edition/9780205585564.html

[7] Hartanto W. Penggunaan E-Learning sebagai Media Pembelajaran. J Pendidik Ekon. 2016;10(1):1-18.

[8] Andrianto Pangondian R, Insap Santosa P, Nugroho E. Faktor - Faktor Yang Mempengaruhi Kesuksesan Pembelajaran Daring Dalam Revolusi Industri 4.0. In: Sainteks 2019 [Internet]. 2019. p. 56-60. Available from: https://seminarid.com/semnas-sainteks2019.html

[9] Jung H, Brady C. Maintaining rich dialogic interactions in the transition to synchronous online learning. Inf Learn Sci [Internet]. 2020 Jun 29 [cited 2021 Jan 14];121(5-6):381-90. Available from:

https://www.researchgate.net/publication/3425308 58_Maintaining_rich_dialogic_interactions_in_the _transition_to_synchronous_online_learning

[10] Wright RD. Student-teacher interaction in online learning environments [Internet]. Student-Teacher Interaction in Online Learning Environments. IGI Global; 2014 [cited 2021 Jan 14]. 1-450 p. Available from: https://www.igiglobal.com/gateway/book/108296

[11] wu W, Chen L, Yang Q. Students' Personality and Chat Room Behavior in Synchronous Online Learning. In Kowloon; 2016. Available from: https://www.researchgate.net/publication/3223293 89_Students\%27_Personality_and_Chat_Room_B ehavior_in_Synchronous_Online_Learning

[12] Johnson GM, Cooke A. An Ecological Model of Student Interaction in Online Learning Environments. In: Multicultural Instructional Design [Internet]. IGI Global; 2020 [cited 2021 Jan 14]. p. 387-415. Available from: http://services.igi-

global.com/resolvedoi/resolve.aspx?doi=10.4018/ 978-1-5225-9279-2.ch018

[13] Tamhankar TK, Pujari VI, Patil RB. Role of Technology In Education: A 21st Century Approach. Int J Sci Res Comput Sci Eng Inf Technol [Internet]. 2019 Apr 4 [cited 2021 Jan 15];1164-8. Available from: https://www.researchgate.net/publication/3374149 77_Role_of_Technology_In_Education_A_21_st_ Century_Approach

[14] Shephard AJ, Pookulangara SA. Student use of university digital collections: the role of technology and educators. Museum Manag Curatorsh [Internet]. 2020 Jul 3 [cited 2021 Jan 15];35(4):392-408. Available from: 
https://www.tandfonline.com/doi/abs/10.1080/096 47775.2019.1638818

[15] Andreassen HM, Holmsen TL. Case-based learning in nursing education. Nord sygeplejeforskning [Internet]. 2018 Oct 1 [cited 2021 Jan 14];8(03):219-29. Available from: www.idunn.no.

[16] Saputra KAK. Case-Based Learning in Forensic Accounting Education. Int $\mathrm{J}$ Educ Vocat Stud [Internet]. 2019 Aug 30 [cited 2021 Jan 14];1(6):545-53. Available from: http://ojs.unimal.ac.id/index.php/ijevsDOI:https:// doi.org/10.29103/ijevs.v1i6.1763 